\title{
A brief taxonomy of the genus Prorocentrum in the coastal areas along Sanya Bay, Hainan Island
}

\author{
Anqi Yin ${ }^{\mathrm{a}, \mathrm{b}, *}$, Xinghua Wang ${ }^{\mathrm{c}}$, Yajian Zhang ${ }^{\mathrm{a}}$, Hongwu $\mathrm{Li}^{\mathrm{d}}$ \\ a College of Life Sciences and Ecology, Hainan Tropical Ocean University, Sanya, Hainan 572022 China \\ b School of Environmental Science, The University of Shiga Prefecture, Hikone, Shiga 522-8533 Japan \\ c School of Ocean Science and Technology, Hainan Tropical Ocean University, Sanya, \\ Hainan 572022 China \\ d State Key Laboratory of Marine Resource Utilization in South China Sea, Haikou, Hainan 570228 China \\ *Corresponding author, e-mail: inanqi@yeah.net
}

Received 7 May 2018

Accepted 14 Aug 2018

\begin{abstract}
This is the first report of the genus Prorocentrum Ehrenberg occurring in the coastal areas along Sanya Bay, Hainan Island. Samples were collected from five coastal stations in 2017, and a brief taxonomy of Prorocentrum species was carried out using an inverted microscope. Five species ( $P$. hoffmannianum, $P$. lima, $P$. micans, $P$. rhathymum, $P$ sigmoides) were identified, including three toxic species and two red tide-forming species. In particular, $P$. hoffmannianum and P. lima were both confirmed as the producers of okadaic acid and responsible for diarrhoetic shellfish poisoning events. This may suggest the potential threats of harmful algal blooms in the coastal areas along Sanya Bay that could cause diarrhoetic shellfish poisoning events.
\end{abstract}

KEYWORDS: dinoflagellates, planktonic, benthic, toxic, red tide-forming

\section{INTRODUCTION}

Dinoflagellates are an important part of the pelagic ecosystem ${ }^{1}$, make a large component of primary producers, and are estimated to make up about $40 \%$ of the total species of marine phytoplankton ${ }^{2}$. Over 2500 dinoflagellate species have been recognized worldwide $^{3}$, and about 76 of these species have been classified as harmful. The harmful species cause water discolorations known as red tides, and sometimes produce toxins that directly kill fish and shellfish or accumulate to lethal levels in highertrophic level consumers in the food chain, including humans ${ }^{4}$. In any aquatic ecosystem, there hardly exist an environmental condition not exploited by dinoflagellates ${ }^{5}$.

High temperature and low salinity are particularly appropriate for the growth of dinoflagellates ${ }^{6}$, and the genus Prorocentrum Ehrenberg, which includes 56 marine species, belongs to the family Prorocentraceae Stein ${ }^{7}$, is one of the most diverse and wide spread genus in the tropical ocean ${ }^{8,9}$. Most of the Prorocentrum species are planktonic and benthic ${ }^{10}$, at least 9 species have been shown to produce toxins ${ }^{11}$, and cause toxic blooms that represent physical danger, such as shellfish poisoning ${ }^{12,13}$.

Sanya, the southernmost part of Hainan Is- land, is located in a tropical climate region, where shellfish industries, fish farming, and tourism have rapidly developed in the coastal areas during the last decade. The development of these activities on land in the coastal areas has resulted in pollutant and nutrient runoff from around those areas and led to serious eutrophication of coastal waters, which is closely related to the frequency of harmful algal blooms (HABs).

In recent years, shellfish poisoning events occurred frequently in Sanya. In this report, we investigated the species of Prorocentrum in the coastal areas along Sanya Bay, and a brief taxonomy was carried out.

\section{MATERIALS AND METHODS}

Five sampling sites were selected along the coastal areas along Sanya Bay $\left(18^{\circ} 12^{\prime} 39^{\prime \prime}-18^{\circ} 17^{\prime} 24^{\prime \prime} \mathrm{N}\right.$ latitude, $109^{\circ} 21^{\prime} 56^{\prime \prime}-109^{\circ} 28^{\prime} 19^{\prime \prime} \mathrm{E}$ longitude); all were chosen as shallow, about $<5 \mathrm{~m}$ deep areas facing the South China Sea (Fig. 1). Phytoplankton samples were qualitatively collected in January and August 2017 , with a $5-\mu \mathrm{m}$-mesh plankton net after prescreening with a $200-\mu \mathrm{m}$-mesh net. These samples were immediately transferred into $100-\mathrm{ml}$ plastic bottles and preserved with glutaraldehyde at a final 


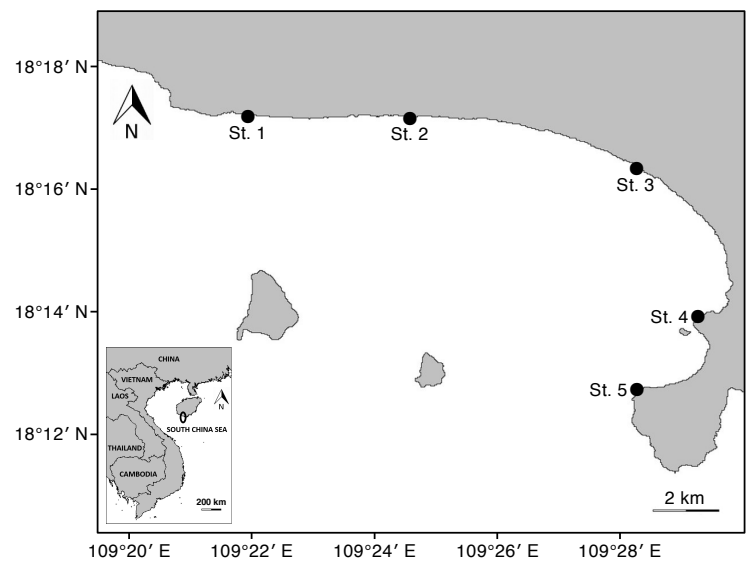

Fig. 1 Map of the Sanya Bay coast showing the sampling locations $(\bullet)$.

concentration of $1 \%$.

Species were observed under an inverted microscope (OLYMPUS, IX71), and if necessary, Calcofluor White M2R at a final concentration of $10 \mu \mathrm{g} / \mathrm{ml}$ was used to stain the outer shells of the dinoflagellates ${ }^{14}$, using an inverted differential interference contrast epifluorescence microscope (OLYMPUS, BX60F) equipped with a UV excitation unit. Photographs of these algae were captured with a charge-coupled device camera (OLYMPUS, DP70). Prorocentrum spp. were identified according to previous literatures ${ }^{3,12,15,16}$.

\section{RESULTS}

The genus Prorocentrum Ehrenberg, which is a desmokont dinoflagellate, characterized by apical insertion of the flagella, absence of the cingulum and the sulcus ${ }^{9}$, and the cell consists of the two lateral thecae, which are joined by the marginal edges ${ }^{12}$. In the present study, five species were from the coastal areas along Sanya Bay as described below.

\section{P. hoffmannianum Faust 1990}

Synonym: Exuviaella hoffmannianum (Faust) McLachlan et Boalch 1997

Cell is ovoid, broadest in the middle region, tapering slightly apically, 45-55 $\mu \mathrm{m}$ in length and 40-45 $\mu \mathrm{m}$ in width, containing golden-brown chloroplasts, a centrally located pyrenoid, and a posterior nucleus. The valves are apically excavated. The periflagellar area is a wide triangle situated apically on the right valve, and it lacks both valve spines and anterior spines (Fig. 2a).
P. hoffmannianum is a benthic species, can be tychoplanktonic, with warm temperate to tropical coastal waters distribution, reported from Belize ${ }^{17}$, and this species was reported to be associated with floating detritus in tropical coastal regions of the Caribbean Sea ${ }^{17}$, attached to macroalgae in the Belizean barrier reef ecosystem ${ }^{18}$.

P. hoffmannianum is usually considered toxic, producing fast-acting toxin and okadaic acid ${ }^{19}$.

\section{P. lima (Ehrenberg) Stein 1878}

Basionym: Cryptomonas lima Ehrenberg 1860

Synonyms: E. marina Cienkowski 1881

Dinopyxis laevis Stein 1883

E. lima (Ehrenberg) Bütschli 1885

E. lima (Ehrenberg) Schütt 1896

E. laevis (Stein) Schroder 1900

E. cincta Schiller 1918

E. marina var. lima (Ehrenberg) Schiller 1931

E. ostenfeldi Schiller 1933

E. caspica Kiselev 1940

P. marinum Dodge et Bibby 1973

P. arenarium Faust 1994

Cells are oblong to ovate, broad in the middle region, narrow at the anterior end, 31-47 $\mu \mathrm{m}$ in length and $22-40 \mu \mathrm{m}$ in width (Fig. $2 \mathrm{~b}, 2 \mathrm{c}$ ), containing a central pyrenoid and a large posterior nucleus (Fig. 2b). The valve surface is covered with scattered pores, but the centre is devoid of the pores, the right valve having valve pores of two different sizes, and the marginal pores are presented (Fig. 2c). The periflagellar area is a wide triangle containing a curved apical collar, void of valve spines or anterior spines (Fig. 2b).

P. lima is a neritic and estuarine, benthic/epiphytic species (can be tychoplanktonic), worldwide distribution, typically in temperate and tropical waters $^{8,20}$, reported from East China Sea and South China Sea ${ }^{21}$; Japan, Indonesia and Philippines ${ }^{22}$, and this species was reported to be attached to macroalgae, or was observed swimming close to the bottom substrate, and was associated with coral reefs ${ }^{17}$, or can be found attached to floating detritus in mangrove habitats ${ }^{23}$.

P. lima is a toxic species known to produce a number of toxic substances, such as fast-acting toxin $^{24}$, and diarrhoetic shellfish poisoning (DSP) toxins including okadaic acid ${ }^{25}$.

\section{P. micans Ehrenberg 1834}

Synonyms: P. schilleri Böhrn 1933 P. levantinoides Bursa 1959 

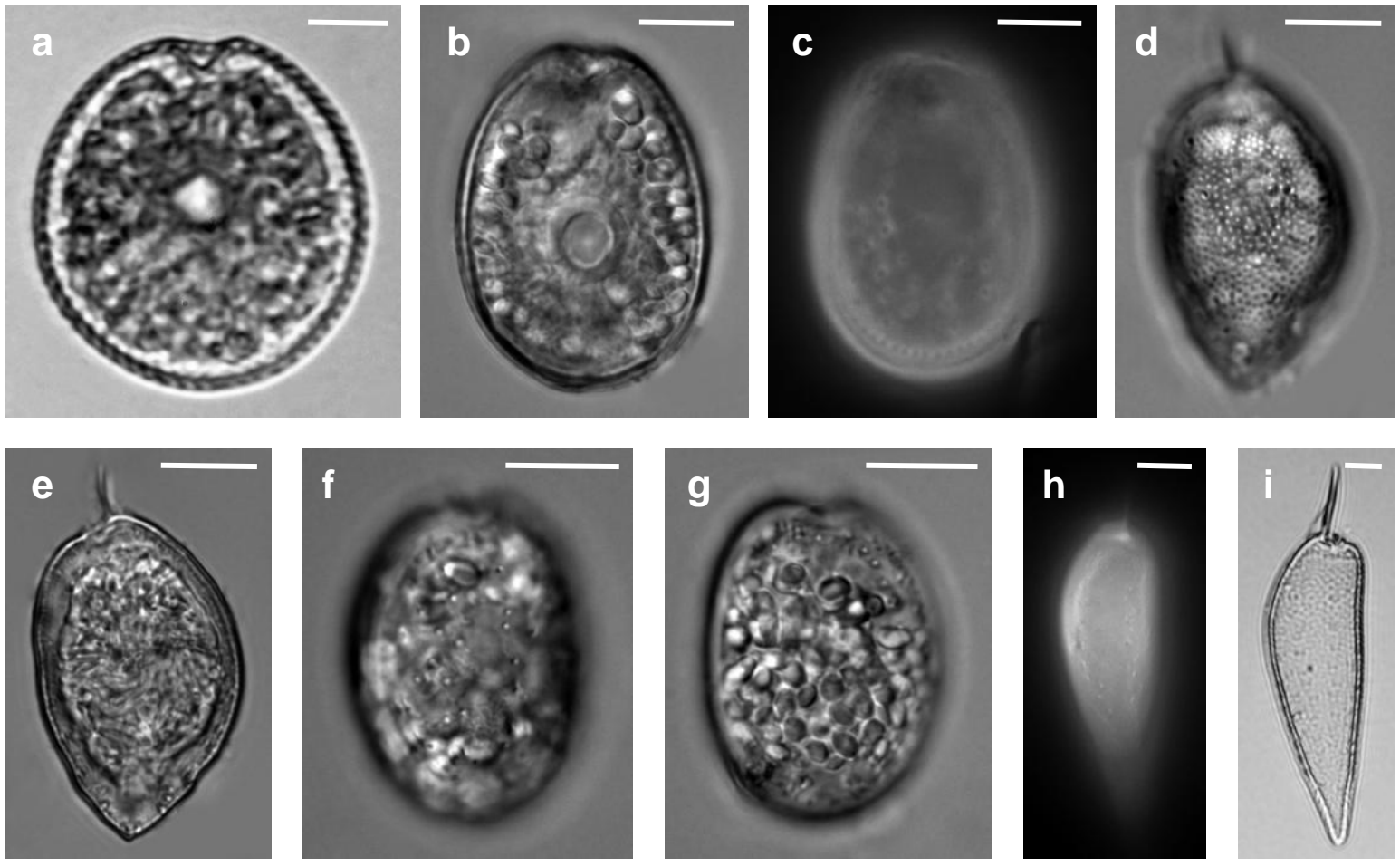

Fig. 2 Light and fluorescence microphotographs of Prorocentrum spp.; (a) P. hoffmannianum, (b, c) $P$. lima, (d, e) P. micans, (f, g) P. rhathymum, (h, i) P. sigmoides. Scale bars $10 \mu \mathrm{m}$.

\section{P. pacificum Wood 1963}

Cells are tear-drop to heart shaped, generally rounded anteriorly, tapering posteriorly, broadest around the middle, 35-70 $\mu \mathrm{m}$ in length and 20$50 \mu \mathrm{m}$ in width (Fig. 2d, 2e). One convex side and one arched side, the convex arch profile is typically in the middle of the cell where is the broadest, and a well-developed winged apical spine is presented (Fig. 2d, 2e). Numerous tubular trichocyst pores are presented in short rows arranged radially (Fig. 2d). The periflagellar area is a relatively small, shallow, broad triangular depression situated apically on the right valve off-centre (Fig. 2e).

P. micans is a neritic and estuarine, planktonic species, but also found in oceanic environments, with cold temperate to tropical waters distribution ${ }^{20}$, reported from Japan ${ }^{16}$; Mexican Pacific Coast $^{13}$; East China Sea and South China Sea ${ }^{21}$.

Although $P$. micans is capable of forming extensive blooms, it is usually considered harmless ${ }^{26}$. It may excrete substances that inhibit diatom growth, but apparently these substances do not enter the food chain or affect organisms at higher trophic levels ${ }^{27}$. Early reports on $P$. micans being a paralytic shellfish poison producer ${ }^{28}$ are unconfirmed, and recent incidents involving shellfish mortality have been attributed to oxygen depletion ${ }^{29}$.

\section{P. rhathymum Loeblich III, Sherley et Schmidt 1979}

Cells are asymmetric, ovate to oblong with straight sides, $30-38 \mu \mathrm{m}$ in length and $20-25 \mu \mathrm{m}$ in width (Fig. 2f, 2g). The valve pores form the line patterns in the posterior part of the valve (Fig. 2f), the marginal pores are presented (Fig. $2 \mathrm{~g}$ ), and the centres of the valves are devoid of pores (Fig. 2f, $2 \mathrm{~g}$ ). The periflagellar area, located apically and off-centre on the right valve, is a relatively small, V-shaped, shallow depression, and the curved periflagellar collar may appear as an apical spine (Fig. 2f, 2g).

P. rhathymum is a neritic and estuarine, benthic species, can be tychoplanktonic, with tropical and subtropical waters distribution ${ }^{20}$, reported from New Caledonia and Ryukyu Islands (Japan) ${ }^{30}$, and this species was reported to be associated with microalgae, dead coral and seagrasses in Malaysia ${ }^{31}$.

$P$ rhathymum may produce toxins with haemolytic activity ${ }^{32}$, and water-soluble fast-acting toxin $^{24}$. 


\section{P. sigmoides Böhm 1933}

Cells are elongated, in 'S' shape, one convex side and one generally straight side, and tapering posteriorly, 60-85 $\mu \mathrm{m}$ in length and 20-30 $\mu \mathrm{m}$ in width (Fig. 2h, 2i). Numerous trichocyst pores are presented (Fig. 2h, 2i). A sharp and tiny apical spine protruded from the anterior side, adjacent to the periflagellar area, sometimes slightly sigmoid, with the presence of an antapical mucron (Fig. 2i).

$P$. sigmoides is a planktonic species, with temperate to tropical waters distribution ${ }^{16}$, reported from South China Sea and Japan ${ }^{21}$.

$P$. sigmoides has never been reported to be a toxin producer, but it is a fish killer $^{33}$, capable of forming extensive blooms, which can consume dissolved oxygen and cause biota kills ${ }^{34}$.

\section{DISCUSSION}

P. hoffmannianum is similar in shape to $P$. lima, but larger and broader with dense areolae, and misidentified as $P$ concavum frequently, but can be distinguished by its ovoid shape and presence of areolae in the centre of the valve ${ }^{30}$. Both $P$. hoffmannianum and $P$. belizeanum have a prominent flared curved apical collar on the left valve bordering the periflagellar area ${ }^{35}$, and lack an apical spine of the periflagellar area ${ }^{17,35}$, although the latter species has a rounder and more prominent collar than the former one, and $P$. hoffmannianum has a more complex platelet configuration $17,20,35$, these two species were still considered as conspecific based on the subtle morphological overlaps found in cell shape, size, and ornamentation ${ }^{36}$. The areolae of $P$. hoffmannianum are distinct from the similar known species $P$. ruetzlerianum, $P$. ruetzlerianum has about 550 pentagonal-shaped areolae per valve while $P$. hoffmannianum has approximately 670 round to oval $\operatorname{areolae}^{17}$, although electron microscope was not performed in the present study, we still consider the current species (Fig. 2a) as P. hoffmannianum, for the cells of $P$. ruetzlerianum are round to ovoid with an average diameter of $28-35 \mu \mathrm{m}^{17}$.

P. lima can be distinguished by its size, shape, narrow periflagellar area and the presence of the valve and the marginal pores. The marginal pores can be used to differentiate $P$. lima at the light microscope level from the other species which are similar in shape, such as $P$. concavum or $P$. compressum ${ }^{37}$.

$P$ micans varies considerably in shape and size, can be confused with closely related species, such as $P$. gracile, $P$ scutellum, and $P$ caribbaeum. $P$ gracile has a strong winged apical spine, and the length- width ratio usually larger than two, while $P$. micans usually smaller than two ${ }^{8} ; P$. scutellum and $P$ caribbaeum are in the same size range as $P$ micans, but $P$ scutellum bears a shorter and broader apical spine, $P$ caribbaeum is heart-shaped and broadest around the anterior end, and $P$ micans is more tear-drop shaped and broadest around the middle ${ }^{15,35}$.

$P$. rhathymum was always considered as a synonym of $P$. mexicanum ${ }^{8}$, but some studies pointed out, the pores are arranged in organized pattern in $P$. mexicanum while disorganized in $P$. rhathymum ${ }^{38}$, and the former one has an apical wing-shaped spine terminating with two or three tips whereas the latter one only one simple spine ${ }^{10,11}$

$P$. sigmoides was proposed as a synonym of P. gracile $^{15}$, then treated as a distinct species for it has been consistently reported in Mexico ${ }^{9,13}$. $P$ sigmoides and $P$ gracile can be distinguished by the length-width ratio and the apical spine, for the former one, the length-width ratio usually larger than three, and the apical spine is on the right valve, sometimes sigmoid, while the latter one has a winged apical spine, sometimes like an arrowhead $^{8,9}$, but it is still difficult to distinguish as either $P$. sigmoides or $P$ gracile for some cells, because they showed a sigmoid valve margin and a straight and long spine, or a slightly sigmoid spine with a straight valve margin, and mainly because there were no morphometric characters exclusive to $P$ sigmoides, it was suggested as a junior synonym of $P$. gracile ${ }^{13}$.

$P$. hoffmannianum, $P$. lima, and $P$. rhathymum, these three species occurred worldwide in the coastal areas, mostly in benthic and epiphytic habi$\operatorname{tats}^{8}$, however, in this study, they were found in the water column, and although quantitative analysis of species populations was not performed, P. rhathymum showed a high concentration clearly. Actually, some literature indicate the benthic species can be pelagic, such as $P$. lima, this species has been found in substantial concentrations in the water column in Eastern Canada ${ }^{39}$, and high concentrations of this species were also found free-living in the subsurface waters of Northern Tunisia ${ }^{40}$, and on the other hand, we should note that, in the present study, all of the sites were chosen as shallow, about $<5 \mathrm{~m}$ deep areas, and these areas always suffering strong waves, and this may also explain why the benthic species appeared.

In this short report, five species of Prorocentrum were described from Sanya Bay, including three toxic species, $P$. hoffmannianum, $P$. lima, and $P$. rhathymum, and two red tide-forming species, $P$ micans and $P$. sigmoides. In particular, both 
P. hoffmannianum and P. lima confirmed a s the producers of okadaic acid and responsible for the DSP events ${ }^{19,25,40}$, while DSP is the most recurrent threat for the shellfish industries ${ }^{40}$, this information may indicate that, the coastal areas along Sanya Bay potentially face the danger of HABs, and close attention must be paid to the DSP events.

Acknowledgements: This work was supported by Hainan Provincial Natural Science Foundation of China (No. 417155), Scientific Research Foundation of Hainan Tropical Ocean University (No. RHDXB201618), and 2016 Institution of Higher Education Science Study Project in the Education Department of Hainan Province (No. Hnky2016ZD-4). We further acknowledge the valuable comments of Syuhei Ban and Shoko Tanabe.

\section{REFERENCES}

1. Hällfors H (2013) Studies on dinoflagellates in the northern Baltic Sea. PhD thesis, Univ of Helsinki.

2. Simon N, Cras AL, Foulon E, Lemée R (2009) Diversity and evolution of marine phytoplankton. CR Biol 332, 159-70.

3. Hoppenrath M, Elbrächter M, Drebes G (2009) Marine Phytoplankton. Selected Microphytoplankton Species from the North Sea around Helgoland and Sylt. $E$, Schweizerbart Science Publishers, Stuttgart.

4. Myat S, Thaw MSH, Matsuoka K, Lay KK, Koike K (2012) Phytoplankton surveys off the southern Myanmar coast of the Andaman Sea: an emphasis on dinoflagellates including potentially harmful species. Fish Sci 78, 1091-106.

5. Smayda TJ (2002) Adaptive ecology, growth strategies and the global bloom expansion of dinoflagellates. $J$ Oceanogr 58, 281-94.

6. Dodge JD, Marshall HG (1994) Biogeographic analysis of the armored planktonic dinoflagellate Ceratium in the North Atlantic and adjacent seas. J Phycol 30, $905-22$.

7. Gómez F (2005) A list of free-living dinoflagellate species in the world's oceans. Acta Bot Croat 64, 129-212.

8. Faust MA, Larsen J, Moestrup $\varnothing$ (1999) Potentially toxic phytoplankton. 3. Genus Prorocentrum (Dinophyceae). In: Lindley JA (ed) ICES Identification Leaflets for Plankton. Leaflet No 184, International Council for the Exploration of the Sea, Denmark, pp $2-24$.

9. Hernández-Becerril DU, Cortes-Altamirano R, Alonso RR (2000) The dinoflagellate genus Prorocentrum along the coasts of the Mexican Pacific. Hydrobiologia 418, 111-21.

10. Gul S, Saifullah SM (2011) The dinoflagellate genus Prorocentrum (Prorocentrales, Prorocentraceae) from the North Arabian Sea. Pak J Bot 43, 3061-5.
11. Hoppenrath M, Chomérat N, Horiguchi T, Schweikert M, Nagahama Y, Murray S (2013) Taxonomy and phylogeny of the benthic Prorocentrum species (Dinophyceae)-A proposal and review. Harmful Algae 27, 1-28.

12. Steidinger KA, Tangen K (1997) Dinoflagellates. In: Tomas CR (ed) Identifying Marine Phytoplankton, Academic Press, London, pp 387-584.

13. Cohen-Fernandez EJ, Castillo EMD, Ugarte IHS, Pedroche FF (2006) Contribution of external morphology in solving a species complex: The case of Prorocentrum micans, Prorocentrum gracile and Prorocentrum sigmoides (Dinoflagellata) from the Mexican Pacific coast. Phycol Res 54, 330-40.

14. Fritz L, Triemer RE (1985) A rapid simple technique utilizing calcofluor white M2R for the visualization of dinoflagellate thecal plates. $J$ Phycol 21, 662-4.

15. Dodge JD (1975) The Prorocentrales (Dinophyceae). II. Revision of the taxonomy within the genus Prorocentrum. Bot J Linn Soc 71, 103-25.

16. Chihara M, Murano M (1997) An Illustrated Guide to Marine Plankton in Japan, Tokai Univ Press, Tokyo.

17. Faust MA (1990) Morphologic details of six benthic species of Prorocentrum (Pyrrophyta) from a mangrove island, Twin Cays, Belize, including two new species. J Phycol 26, 548-58.

18. Morton SL, Faust MA (1997) Survey of toxic epiphytic dinoflagellates from the Belizean barrier reef ecosystem. B Mar Sci 61, 899-906.

19. Aikman KE, Tindall DR, Morton SL (1993) Physiology, potency of the dinoflagellate Prorocentrum hoffmannianum (Faust) during one complete growth cycle. In: Smayda TJ, Shimizu Y (eds) Toxic Phytoplankton Blooms in the Sea, Elsevier, Amsterdam, pp 463-8.

20. Steidinger KA, Tangen K (1996) Dinoflagellates. In: Tomas CR (ed) Identifying Marine Diatoms and Dinoflagellates, Academic Press, New York, pp 387-584.

21. Lu DD (2008) Phylum Dinozoa Cavalier-Smith, 1981. In: Liu JY (ed) Checklist of Biota of Chinese Seas, Science Press, Beijing, pp 175-86.

22. Nagahama Y, Murray S, Tomaru A, Fukuyo Y (2011) Species boundaries in the toxic dinoflagellate Prorocentrum lima (Dinophyceae, Prorocentrales), based on morphological and phylogenetic characters. $J$ Phycol 47, 178-89.

23. Faust MA (1991) Morphology of ciguatera-causing Prorocentrum lima (Pyrrophyta) from widely differing sites. $J$ Phycol 27, 642-8.

24. Tindall DR, Miller DM, Bomber JW (1989) Culture and toxicity of dinoflagellates from ciguatera endemic regions of the world. Toxicon 27, 83.

25. Marr JC, Jackson AE, McLachlan JL (1992) Occurrence of Prorocentrum lima, a DSP toxin-producing species from the Atlantic coast of Canada. $J$ Appl 
Phycol 4, 17-24.

26. Graneli E, Sundstrom B, Edler L, Anderson DM (1990) Toxic Marine Phytoplankton, Elsevier, New York.

27. Uchida T (1977) Excretion of a diatom-inhibitory substance by Prorocentrum micans Ehrenberg. Jap $J$ Ecol 27, 1-4.

28. Pinto JSD, Silva EDSE (1957) The toxicity of Cardium edule L. and its possible relation to the dinoflagellate Prorocentrum micans Ehr. Jornal da Sociedade das Ciências Médicas de Lisboa 121, 304-26.

29. Lassus P, Berthome JP (1988) Status of 1987 Algal Blooms in IFREMER, International Council for the Exploration of the Sea/Annex III C, Copenhagen.

30. Fukuyo Y (1981) Taxonomical study on benthic dinoflagellates collected in coral reefs. Bull Japan Soc Sci Fish 47, 967-78.

31. Mohammad-Noor N, Daugbjerg N, Moestrup $\emptyset$, Anton A (2007) Marine epibenthic dinoflagellates from Malaysia - a study of live cultures and preserved samples based on light and scanning electron microscopy. Nord J Bot 24, 629-90.

32. Nakajima I, Oshima Y, Yasumoto T (1981) Toxicity of benthic dinoflagellates in Okinawa. Bull Japan Soc Sci Fish 47, 1029-33.

33. Lu S, Hodgkiss IJ (2004) Harmful algal bloom causative collected from Hong Kong waters. Hydrobiologia 512, 231-8.

34. Ajuzie CC, Houvenaghel GT (2009) Preliminary survey of potentially harmful dinoflagellates in Nigeria's coastal waters. Fottea 9, 107-20.

35. Faust MA (1993) Prorocentrum belizeanum, Prorocentrum elegans and Prorocentrum caribbaeum, three new benthic species (Dinophyceae) from a mangrove island Twin Cays, Belize. J Phycol 29, 100-7.

36. Herrera-Sepúlveda A, Medlin LK, Murugan G, SierraBeltrán AP, Cruz-Villacorta AA, Saavedra NYH (2015) Are Prorocentrum hoffmannianum and Prorocentrum belizeanum (DINOPHYCEAE, PROROCENTRALES), the same species? An integration of morphological and molecular data. $J$ Phycol 51, 173-88.

37. Steidinger KA (1983) A re-evaluation of toxic dinoflagellate biology and ecology. Prog Phycol Res 2, 147-88.

38. Cortés-Altamirano R, Sierra-Beltrán AP (2003) Morphology and taxonomy of Prorocentrum mexicanum and reinstatement of Prorocentrum rhathymum (Dinophyceae). J Phycol 39, 221-5.

39. Bates SS (1997) Toxic phytoplankton on the Canadian east coast: implications for aquaculture. Bull Aquacul Assoc Canada 97, 9-18.

40. Sahraoui ID, Bouchouicha D, Mabrouk HH, Hlaili AS (2013) Driving factors of the potentially toxic and harmful species of Prorocentrum Ehrenberg in a semi-enclosed Mediterranean lagoon (Tunisia, SW Mediterranean). Medit Mar Sci 14, 353-62. 